\title{
Design and Testing of a Solar Torrefaction Unit to Produce Charcoal
}

\author{
Rajaram Swaminathan*, Frans Nelongo Pandeni Nandjembo \\ Department of Mechanical and marine Engineering, Namibia University of Science and Technology, Windhoek, \\ Namibia \\ Email: "rswaminathan@nust.na
}

Received 4 April 2016; accepted 7 August 2016; published 10 August 2016

Copyright (C) 2016 by authors and Scientific Research Publishing Inc.

This work is licensed under the Creative Commons Attribution International License (CC BY).

http://creativecommons.org/licenses/by/4.0/

(c) (i) Open Access

\begin{abstract}
With increasing crude oil prices, fuels like kerosene and cooking gas have become unaffordable for many ordinary people in developing countries. For millions of Africans who need heat energy to cook their food, biomass like wood remains the easiest and cheapest source of fuel. Charcoal remains the most popular choice compared to wood since it can cook food much faster with very little smoke. Torrefaction of biomass is a mild form of pyrolysis at temperatures typically between $200^{\circ} \mathrm{C}$ and $300^{\circ} \mathrm{C}$ to produce charcoal. Torrefaction changes biomass properties to provide a much better fuel quality for combustion applications. A simple parabolic trough solar collector to produce charcoal by torrefaction process using solar energy has been designed from first principles. The device was fabricated and various locally available wood species were tested. The yield was found to be $21 \%$ to $35 \%$ with a production time of 90 minutes. The paper details the design procedure and the test results.
\end{abstract}

\section{Keywords}

Torrefaction, Charcoal Production, Solar Parabolic Trough, Design, Testing

\section{Introduction}

Charcoal is in high demand in many parts of Africa, since it contains double the energy of ordinary firewood and burns much better [1]. Charcoal is produced by several methods [2]. These are mostly batch processes like i) Earth pits and mounds (yield > 10\%), ii) Brick, concrete, and metal kilns (yield 20\% - 25\%) and iii) Retorts (yield 30\%). In all these processes the heat for the process is provided directly as the heat of reaction or by the flue gases from combustion to the reactor or through the reactor wall.

"Corresponding author. 
Use of solar energy for the charcoal production process has the following advantage: Reaction temperature can be maintained between $200^{\circ} \mathrm{C}$ to $300^{\circ} \mathrm{C}$ enabling torrefaction of the biomass. Torrefied biomass has several advantages like higher energy density, more homogeneous composition, hydrophobic behaviour (water repulsion) and elimination of biological decomposition like rotting [3].

\section{Description of Solar Torrefaction Unit}

A solar concentrator captures solar radiation over a large aperture as illustrated below in Figure 1 [4]. The aperture is covered with a highly reflective material to allow light to be reflected on the focal point. The solar radiation energy is concentrated on a small tube area (receiver tube) containing biomass. The process of concentrating solar energy enables the heating of biomass in the tube to produce charcoal.

Since the sun appears to be moving from east to west daily and north to south annually, the dish must also move in the same direction and at the same speed of the sun so as to face the sun.

To maintain the trough facing the sun all the time during usage, a sun tracking system is required. However for the present unit a manual sun tracking system is incorporated. The Parabolic Trough y-axis was aligned to be parallel to the sun light by turning the tracking mechanism at an interval of 15 degree per hour. The Unit is positioned in such a way that its angle can be changed according to the latitude of the location, for example Windhoek's latitude is $22^{\circ} 33^{\prime} \mathrm{S}, 17^{\circ} 4^{\prime} \mathrm{E}$.

The receiver tube is made from low emissivity borosilicate glass (glass with a very low iron content that has superior durability and heat resistance) with an all-glass seal and Aluminum-Nickel selective coating. Further, the tubes are evacuated and have a barium getter (vacuum indicator) which changes color from silver to white if a tube's vacuum has been compromised.

The evacuated tube has high thermal efficiency in bright sunshine as well as overcast or diffuse sunlight conditions. An examination of the tubes shows that the outside is actually 2 layers of glass and a vacuum has been created between them.

\section{Design Basis}

The biomass considered for design is wood with a moisture content of $m \%$. Hence, $1 \mathrm{~kg}$ of wood with $m \%$ moisture content consists of $(1-m) / 100 \mathrm{~kg}$ of dry wood and $m / 100 \mathrm{~kg}$ of water. It is assumed that the moisture content is totally removed when the wet wood is heated from ambient temperature to $100^{\circ}$. Hence the energy required for drying $1 \mathrm{~kg}$ of wet wood is given by:

$$
E_{\text {drying }}=(1-m) \times C_{p} \times\left(100-t_{i}\right)+m \times C_{p w} \times\left(100-t_{i}\right)+L
$$

$t_{i}=$ ambient temperature; $C_{p}=$ specific heat of wood $=1.76 \mathrm{~kJ} \cdot \mathrm{kg} \cdot \mathrm{K}$.

$C_{p w}=$ specific heat of water $=4.186 \mathrm{~kJ} \cdot \mathrm{kg} \cdot \mathrm{K} ; L=$ heat of vaporization $=2265 \mathrm{~kJ} / \mathrm{kg}$.

Torrefaction is an endothermic process requiring about $600-1000 \mathrm{~kJ} / \mathrm{kg}$. The energy which torrefaction reaction absorbs is assumed to be $800 \mathrm{~kJ} / \mathrm{kg}$ [5]. Hence energy required for torrifying $1 \mathrm{~kg}$ of dry wood is given by

$$
E_{\text {torr }}=(1-m) \times C_{p} \times\left(T_{t}-100\right)+800
$$

Therefore, total energy required by the process for $1 \mathrm{~kg}$ of wet wood input is,

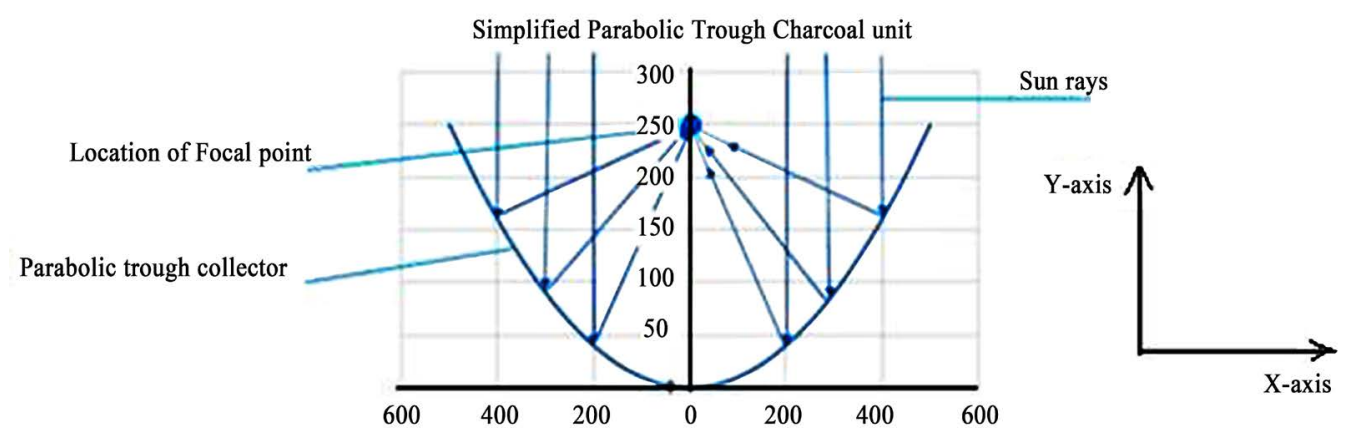

Figure 1. Indicates the focal point in the parabolic trough collector. 


$$
E_{\text {total }}=E_{\text {drying }}+E_{\text {torr }}
$$

This is the heat energy to be supplied per kg of wet wood by solar energy in the Solar Torrefaction unit. $\therefore$ $E_{\text {total }}=E_{\text {sol }}$.

Referring to the solar collector (Figure 2), rim angle of $90^{\circ}$ is adopted to give wider exposure as indicated in Figure 2. For $90^{\circ}$ rim angle, the ratio of focal length/diameter $(f / d)=0.25$ as indicated in Figure 2.

Referring to the parabolic solar collector, the total radiation incident on the parabolic solar collector is given by

$$
\begin{gathered}
E_{\text {sol }}=\text { Collector Area } \times \text { Average Solar Radiation } \times \text { Collector Efficiency } \\
E_{\text {sol }}=\text { Collector Area } \times \text { Average Solar Radiation in } \mathrm{J} / \mathrm{s} \cdot \mathrm{m}^{2} \times t \times \text { Collector Efficiency }
\end{gathered}
$$

(Average Solar Radiation is expressed in $\mathrm{W} / \mathrm{m}^{2} \quad\left(=\mathrm{J} / \mathrm{s} \cdot \mathrm{m}^{2}\right)$ and $t$ is the time taken for the process) then solar energy available $=E_{\text {sol }}=\left(E_{\text {tot }} \times 1000\right)$, since $E_{\text {tot }}$ is in kilo Joules.

$$
\therefore \text { Collector Area }=\frac{\left(E_{\text {tot }} \times 1000\right)}{\text { Average Solar Radiation in } \mathrm{J} / \mathrm{s} \cdot \mathrm{m}^{2} \times t \times \text { Collector Efficiency }}
$$

The Collector area of parabolic trough is given by

$$
A=\left[\frac{d}{2} \sqrt{1+\frac{d^{2}}{16 f^{2}}}+2 f \ln \left(\frac{d}{4 f}+\sqrt{1+\frac{d^{2}}{16 f^{2}}}\right)\right] \times l \text {, where } l=\text { length of the trough }
$$

Equation (4) can be used to calculate the Collector area for torrefaction of $1 \mathrm{~kg}$ of wood. If the rim angle and aperture diameter are fixed, the length of the collector can be calculated from Equation (5).

\section{Sample Calculation}

Assumptions:

Moisture in wood $=10 \%$; Rim angle of $90^{\circ}$; Aperture diameter, $d=1 \mathrm{~m}$, process time, $t=1 \mathrm{~h}=3600 \mathrm{~s}$.

Focal length $f=0.25$ since $(f / d)=0.25$ for rim angle of $90^{\circ}$.

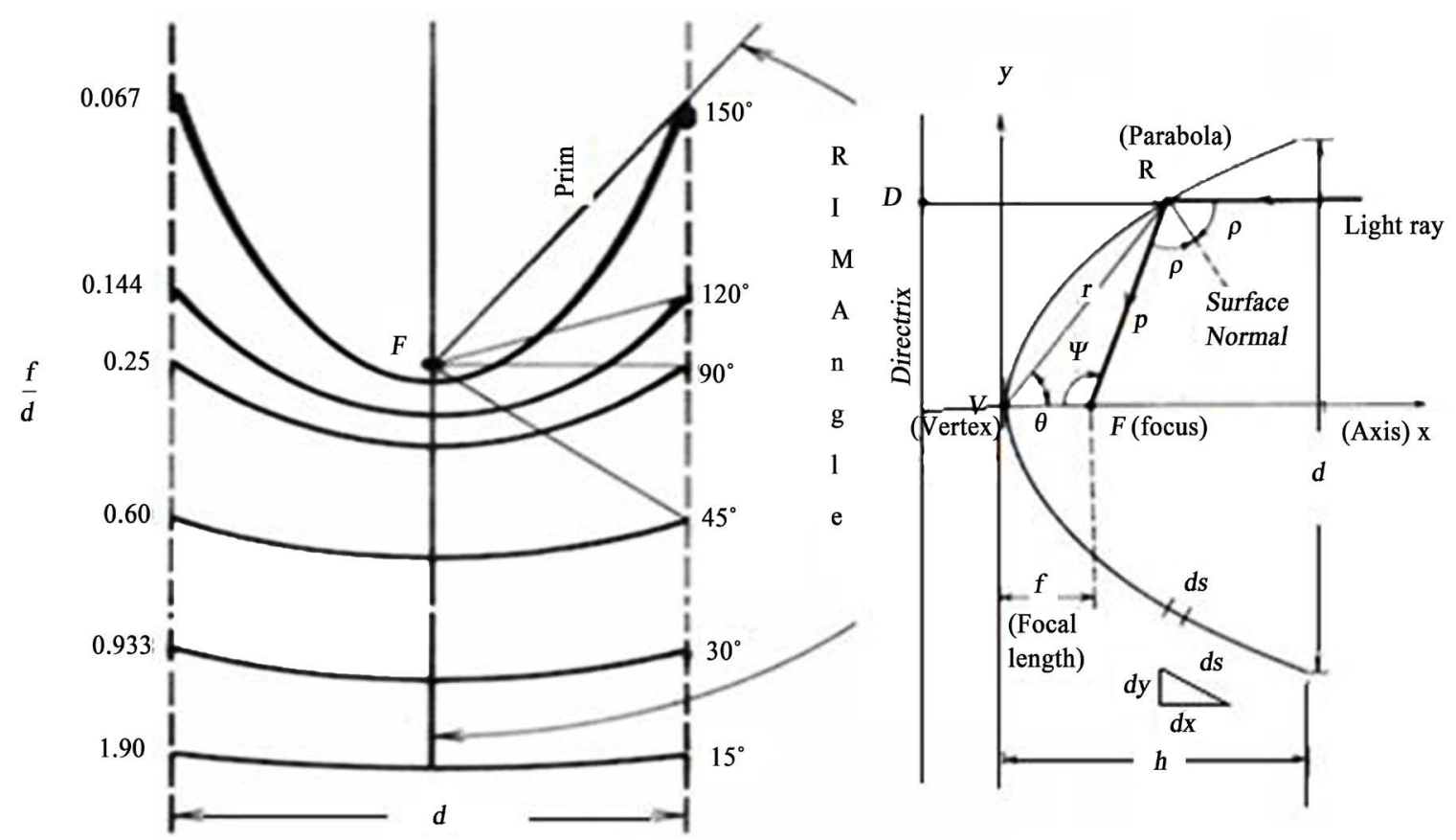

Figure 2. The critical points in the parabolic collector. 
From (1)

$$
E_{\text {drying }}=0.9 \times 1.76 \times(100-20)+0.1 \times[4.186 \times(100-20)+2265]=126.72+259.99=386.71 \mathrm{~kJ} / \mathrm{kg}
$$

From (2)

$$
E_{\text {torr }}=(0.9) \times[1.76 \times(300-100)+800]=1036.8 \mathrm{~kJ} / \mathrm{kg}
$$

From (3)

$$
E_{\text {total }}=E_{\text {drying }}+E_{\text {torr }}=386.71+1036.8=1423.5 \mathrm{~kJ} / \mathrm{kg}
$$

With an average solar radiation of $675 \mathrm{~W} / \mathrm{m}^{2}\left(=\mathrm{J} / \mathrm{s} \cdot \mathrm{m}^{2}\right)$ in Windhoek, Namibia [6], and collector efficiency of 70\%, substituting in Equation (4), the collector area required works out to,

$$
\begin{aligned}
& \therefore \text { Collector Area }=\frac{\left(E_{\text {tot }} \times 1000\right)}{\text { Average Solar Radiation in } \mathrm{J} / \mathrm{s} \cdot \mathrm{m}^{2} \times t \times \text { Collector Efficiency }} \\
& =1423.5 \times \frac{1000}{600 \times 3600 \times 0.70}=0.836 \mathrm{~m}^{2}
\end{aligned}
$$

This is the collector area required for torrefaction of $1 \mathrm{~kg}$ of wood in 1 hour.

The Collector area of parabolic trough is given by (5) as,

$$
A=\left[\frac{d}{2} \sqrt{1+\frac{d^{2}}{16 f^{2}}}+2 f \ln \left(\frac{d}{4 f}+\sqrt{1+\frac{d^{2}}{16 f^{2}}}\right)\right] \times l \text { where } l=\text { length of the trough. }
$$

Substituting the values,

$$
A=\left[\frac{1}{2} \sqrt{1+\frac{1^{2}}{16 \times 0.25^{2}}}+2 \times 0.25 \times \ln \left(\frac{1}{4 \times 0.25}+\sqrt{1+\frac{1^{2}}{16 \times 0.25^{2}}}\right)\right] \times l=1.148 \times l \mathrm{~m}^{2}
$$

Required length $l$ is given by, $1.148 \times l=0.836 \rightarrow l=0.728 \mathrm{~m}$.

\section{Test Results}

A solar torrefaction unit based on the above design was constructed and tested [7]. Figure 3 shows the unit.

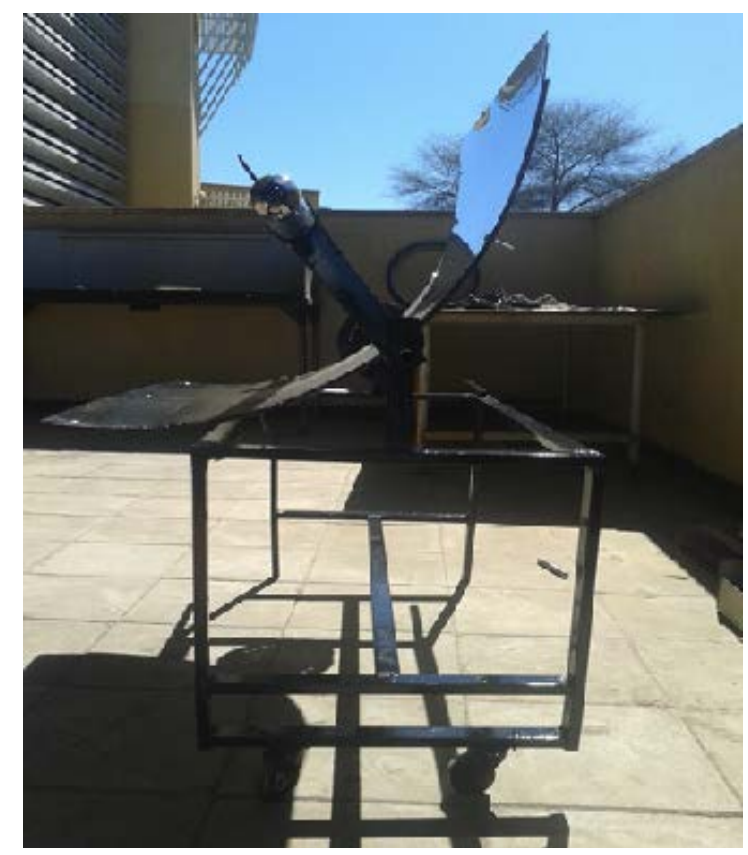

Figure 3. The unit. 
The Parabolic Trough y-axis was aligned to be parallel to the sun light by turning the tracking mechanism at an interval of 15 degree per hour. Three types of wood (Acacia, Berchemia discolor and White oak) were placed inside the tube for testing and time taken for torrefaction was recorded. The receiver tube inside temperature was of the order of $300^{\circ} \mathrm{C}-320^{\circ} \mathrm{C}$. The tube inside temperature recorded at regular interval starting at $9 \mathrm{AM}$ is given in Figure 4.

After the completion of the process, the charcoal from the three types of wood was weighed, and charcoal yield was calculated. Charcoal yield was calculated by the following:

$$
\text { charcoal yield }(\%)=\frac{\text { weight of charcoal }(\mathrm{kg})}{\text { oven dry weight of wood material }(\mathrm{kg})} \times 100 \%
$$

The results are tabulated below.

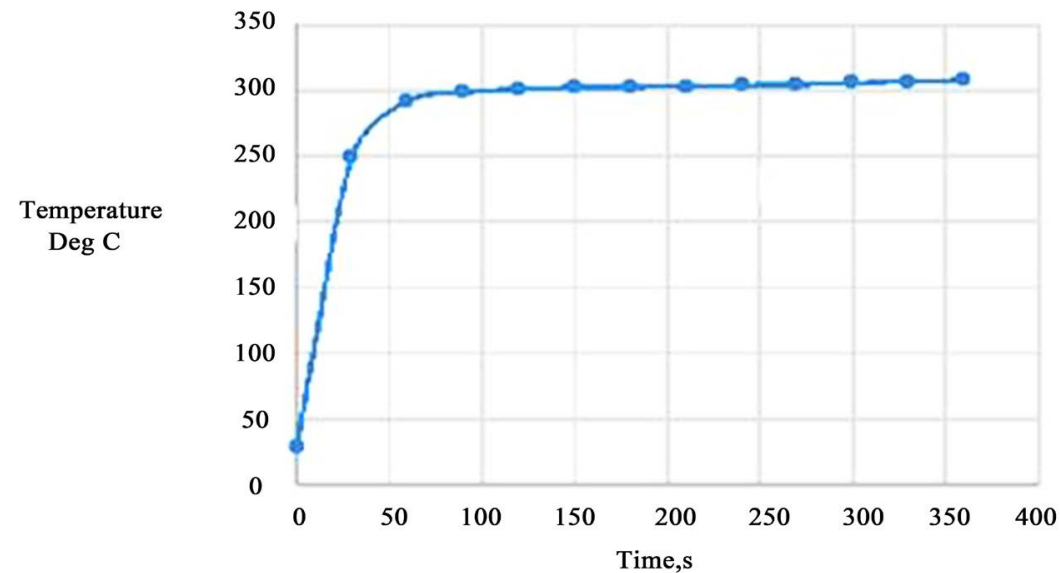

Figure 4. The tube inside temperature recorded at regular interval starting at 9AM.

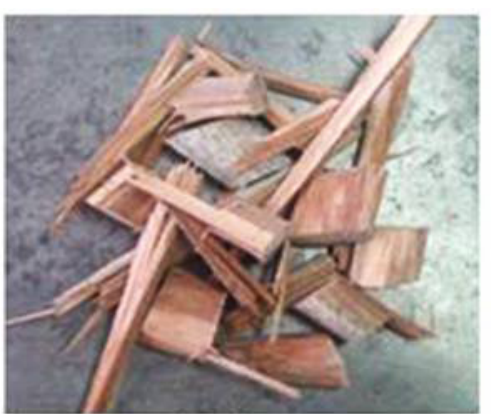

Acacia

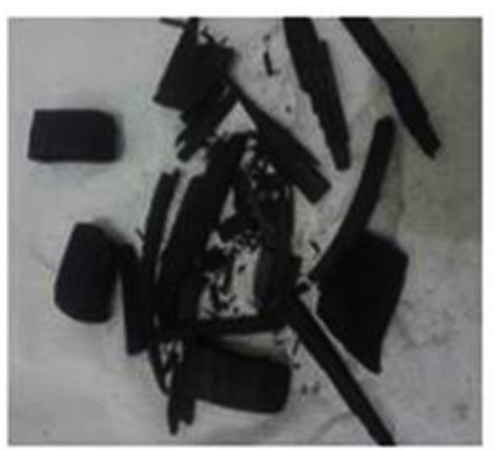

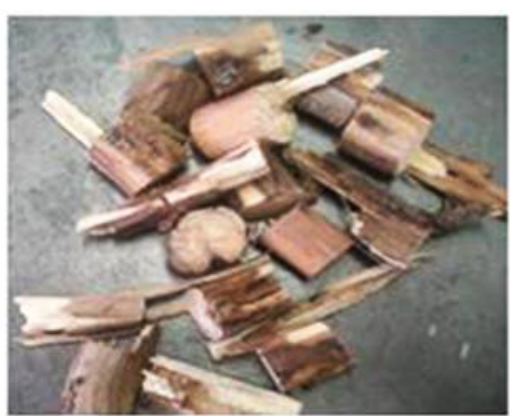

Berchemia

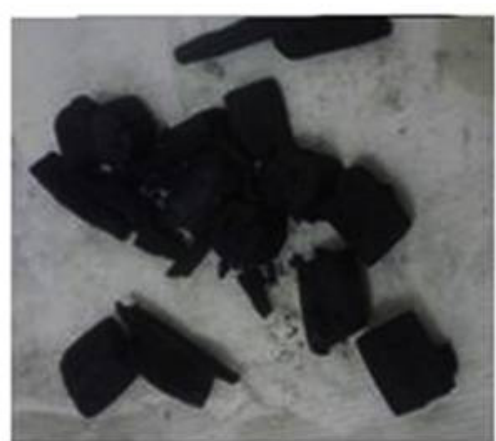

Charcoal

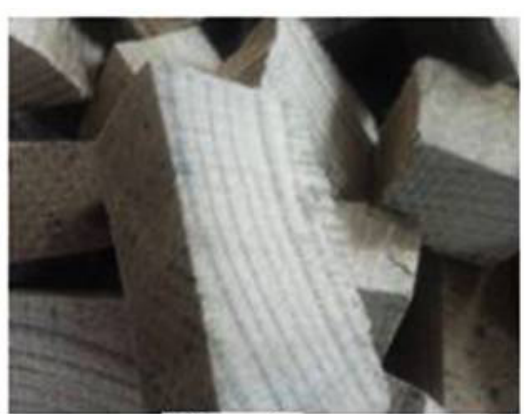

White oak

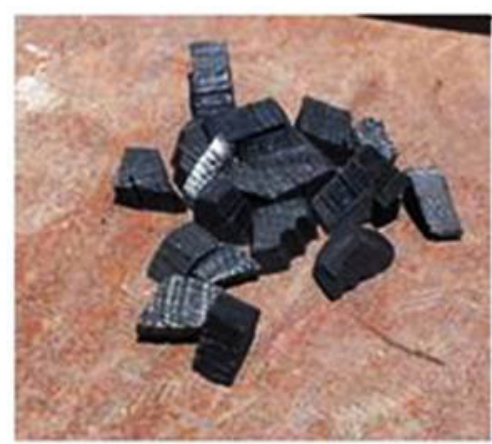

Figure 5. Shows the different woods tested and the charcoal obtained. 


\begin{tabular}{ccc}
\hline Type of wood & Time for charcoal production (h) & Charcoal yield \% \\
\hline White Oak Charcoal & $01 ; 30$ & 21 \\
Berchemia discolor & $01 ; 30$ & 35 \\
Acacia & $01 ; 30$ & 28 \\
\hline
\end{tabular}

The time taken for these types of wood is the same Figure 5. The yield ranges from 21\% - 35\% depending on the wood. It is observed that the charcoal of white oak is lighter than those of Acacia and Berchemia.

\section{Conclusion}

Basic principles in the design of Solar Torrefaction unit have been identified and a design methodology has been developed from the first principles. The unit designed as per these procedures are found to work well. The simple design methodology developed is found to be adequate.

\section{Acknowledgements}

The authors thank the management of the Namibia University of Science and Technology for the support and encouragement.

\section{References}

[1] Africa’s Addiction to Charcoal—Everything You Need to Know about This Billion-Dollar Business! http://www.smallstarter.com/

[2] Czernik, S. (2008) Fundamentals of Charcoal Production. IBI Conference on Biochar, Sustainability and Security in a Changing Climate, Newcastle, 8-10 September 2008.

[3] (2014) Torrefaction-A New Process in Biomass and Bio Fuels. New Energy and Fuel. November 19, 2008. Retrieved February 29, 2012 Vol. 2014

[4] Stine, W.B. and Geyer, M. (2001) Power from the Sun. http://www.powerfromthesun.net/index.html

[5] Syu, F.-S. and Chiueh, P.-T. (2012) Process Simulation of Rice Straw Simulation. Sustainable Environmental Research, 22, 177-183.

[6] Namibia Weather (2013) Windhoek Weather Station History. http://weather.namsearch.com/wdhhighlow.php

[7] Nandjembo, F.N.P. (2015) Design and Manufacture of an Improved Solar Charcoal Unit. Polytechnic of Namibia, B. Tech Project.

\section{Submit or recommend next manuscript to SCIRP and we will provide best service for you:}

Accepting pre-submission inquiries through Email, Facebook, LinkedIn, Twitter, etc. A wide selection of journals (inclusive of 9 subjects, more than 200 journals)

Providing 24-hour high-quality service

User-friendly online submission system

Fair and swift peer-review system

Efficient typesetting and proofreading procedure

Display of the result of downloads and visits, as well as the number of cited articles

Maximum dissemination of your research work

Submit your manuscript at: http://papersubmission.scirp.org/ 